\title{
ESCALATION IN STUDENTS' SCIENCE PROCESS SKILLS ON CHAPTER WAVE VIBRATION AND SOUND THROUGH GUIDED INQUIRY LEARNING MODEL
}

\author{
Mia Permata Sari', Winarti ${ }^{1}$ \\ ${ }^{1}$ Physics Education Study Program, Universitas Islam Negeri Sunan Kalijaga, Indonesia \\ E-mail: winarti@uin-suka.ac.id
}

\begin{abstract}
ABSTRAK
Penelitian ini bertujuan untuk mengetahui: (1) pengaruh model inkuiri terbimbing terhadap keterampilan proses sains siswa, (2) peningkatan keterampilan proses sains siswa dengan pembelajaran model inkuiri. Penelitian ini merupakan penelitian quasi experiment dengan non-equivalent control group design. Teknik pengumpulan data yang digunakan adalah tes dan non tes. Instrumen pada penelitian ini adalah lembar soal pretest-posttest kemampuan kognitif, lembar kerja siswa dan lembar observasi keterampilan proses sains. Teknik analisis data yang digunakan adalah statistik non-parametrik dengan uji U Mann Whitney, Normalized Gain (N-Gain) dan analisis deskriptif. Hasil penelitian ini adalah bahwa (1) Pembelajaran fisika menggunakan model pembelajaran inkuiri terbimbing berpengaruh terhadap kemampuan kognitif siswa dengan taraf signifikansi (sig. 2-tailed) sebesar 0,013. (2) Pembelajaran fisika menggunakan model pembelajaran inkuiri terbimbing dapat meningkatkan kemampuan kognitif siswa dengan nilai rerata n-gain sebesar 0,701 yang termasuk dalam kriteria tinggi.
\end{abstract}

Kata kunci: Inkuiri Terbimbing, Keterampilan Proses Sains, Getaran Gelombang dan Bunyi.

\begin{abstract}
This study aims to determine: (1) the effect of guided inquiry models on students' science process skills, (2) improvement of skills the science process of students with learning inquiry models, this research is a quasiexperimental study with non-equivalent control group design. Data collection techniques used were test and non-test. The instruments in this study were a pretest-posttest cognitive ability test sheet, student worksheets and an observation sheet for science process skills. The data analysis technique used is non-parametric statistics with the Mann Whitney U test, Normalized Gain (N-Gain) and descriptive analysis. The results of this study are that (1) Physics learning using guided inquiry learning models influences the cognitive abilities of students with a significance level (sig. 2-tailed) of 0.013. (2) Physics learning using guided inquiry learning models can improve students' cognitive abilities with an average value of n-gain of 0.701 which is included in the high criteria.
\end{abstract}

Keywords: Guided Inquiry, Science Process Skills, Cognitive Skills, Wave Vibration and Sound.

DOI: http://dx.doi.org/10.15575/jotalp.v5i2.8613

Received: 29 Mei 2020 ; Accepted: 16 Juni 2020 ; Published: 31 Agustus 2020 


\section{INTRODUCTION}

Natural Sciences or Ilmu Pengetahuan Alam (IPA) is a knowledge obtained from observation and experiment on natural phenomena. The attempts on conducting the conceptual findings in natural sciences are arranged objectively, methodically, systematically, and universally by using scientific methods. Consequently, science involves the ability to think, attitude skills, and processing skills in solving problems that occur in nature. Science subjects are intended for students in order to have the ability to: 1) develop an understanding of various natural phenomena, concepts, and principles of science that are useful and can be applied in daily life and 2) enhance the knowledge, concepts and skills of science as a basis for sustaining education to the next level (Kemdikbud, 2017).

The mastery learning of basic or fundamental science in junior high is very important in the formation of concepts predilection as the conceptual understanding would be carried out to the next material at a higher level, namely high school and also college if students attend the science field of education. The role of the teacher becomes very important to develop good concepts (Winarti, 2020). Science learning will be very meaningful if students do not only accept material theoretically, but they also need to regain and topple various scientific experiences. Consequently, students can reconstruct their conceptual understanding to scientific concepts based on concrete findings (Wartono et al., 2019).

According to Nworgu \& Otum (2013), science process skills are very potent for every student as a provision to use scientific methods in developing science from and to students in the future. Additionally, science process skills help students to acquire scientific understanding using their own language of explanation so students are expected to elevate new knowledge or develop existing knowledge. Learning activities will be achieved optimally if there is a supportive learning environment, such as a good, effective, challenging and enjoyable learning process. The most important aspect in learning physics is students who are actively studying physics while teacher is in charge of preparing materials to be taught optimally (Suparno, 2007). Based on the results of research conducted at one of the state junior high schools or Sekolah Menengah Pertama (SMP) Negeri in Yogyakarta, we found that the learning process has not facilitated students to have balanced scientific process skills and cognitive abilities. Likewise learning process was still teacher-centered. The teachers were using lectures, discussions, and demonstrations as learning methods occasionally. The minimum intensity of experiment activities caused students to not being accustomed in doing scientific work. Then, it reflected in low science process skills.

Based on the interviews and observations results of learning process, students had held difficulty in the process of preparing a hypothesis and conclusions when a problem in learning was presented. In addition, students had the difficulty in planning experiments when faced with tools and materials. Due to the experiment, students were required to have proper science process skills. Arranging hypotheses, planning experiments, and drawing conclusions in learning are part of the indicators of science process skills. The comparative table of science process skills aspects are presented in Table 1.

Table 1. Comparative Table of Science Process Skills Aspects

\begin{tabular}{ll}
\hline \multicolumn{1}{c}{ Researcher } & \multicolumn{1}{c}{ Science Process Skills Aspects } \\
\hline Funk (1985) & $\begin{array}{l}\text { Observe, classify, predict, measure, infer, } \\
\text { and communicate. }\end{array}$ \\
\hline Dahar (1988) & $\begin{array}{l}\text { Observe, interpret observations, predict, } \\
\text { use tools / materials, apply concepts, plan } \\
\text { research, communicate, and ask questions. }\end{array}$ \\
\hline Semiawan & $\begin{array}{l}\text { Observation (count, measure, classify, } \\
\text { looking for relationships (space / time), } \\
\text { (1990) }\end{array}$ \\
\hline $\begin{array}{l}\text { Rustaman et } \\
\text { research, control variables, interpret data. }\end{array}$ \\
$\begin{array}{l}\text { Observe, formulate hypotheses, design and } \\
\text { conduct experiments, analyze data, } \\
\text { conclude, and communicate. }\end{array}$ \\
\hline
\end{tabular}


Learning is one of complex activities yet challenging enough to conquer understanding because it involves various elements including the existence of communication between students and teachers, the material being taught, and supporting facilities and infrastructure. The most important elements in good learning environment are: (1) students who learn, (2) teachers who teach, (3) learning materials, and (4) relationships between teachers and students (Suparno, 2007). The most important element in physics learning is students' activity on written, spoken, and eye observation. The second potent step is conceptual analysis. As students need to construct their understanding through conceptual analysis, then teachers' job is to motivate, direct, encourage, and guide students in constructing knowledge through various discoveries. Later, conceptual understanding can last long in students' memory.

The selection and determination of effective learning models can be used as an alternative solution in an effort to overcome the above problems (Wartono et al., 2019). One of developed learning models based on constructivism that has been widely attained is guided inquiry learning model. The guided inquiry learning model is a design of teaching and learning requiring its implementation through the steps of the scientific method (Istiyono et al., 2014). The guided inquiry learning model is a student-centered learning model so that students are being given an important role during the learning process. One of important roles students do is included in the lesson design, such as discovery of facts and physical concepts that lead to other concepts. Then, the conceptual findings would be stored longer in their minds and logical fallacy to hoping in other conceptual understanding (Prabowo, 2015). Students are also required to find their own concepts under teachers' instructions and guidance. Usually the teacher gives questions to students so that they are helped in thinking and processing their experiences about the physical problems given during the lesson. With this process, students will be encouraged to conduct empirical experiments to find answers to these problems within the pilot activities. It is the process skills that students use (Deta \& Widha, 2013; Nworgu \& Otum, 2013; Prabowo, 2015; Trianto, 2014). By conducting inquiry-based learning, students can hone their science process skills.

\section{METHOD AND MATERIAL}

The indicators of science process skills used in this study are defined as follows: 1) Observing aspect: students use their sense of sight to determine and collect objects / facts that are relevant to the concepts of vibrations, waves, and sounds; 2) Formulating hypotheses aspect: students formulate hypotheses regarding observational objects related to vibrations, waves, and sounds; 3) Designing and conducting experiments aspect: students are guided to determine the variables, tools, and materials used and to experiment material on vibrations, waves, and sounds; 4) Analyzing data aspect: students are guided to process and calculate data from the results of experiments on vibration, waves, and sound. 5) Concluding aspect: students determine the results of the experiment that are consistent with the purpose of the experiment and are relevant to vibrations, waves, and sounds; and 6) Communicating aspect: students deliver the results of experiments vibration, waves, and sound. The six indicators were used as items designs and each indicator has several questions. These indicators were obtained due to observation and written paper and pencil test. Both results were compared in data analysis.

The guided inquiry learning model is a learning model that implements the steps of the scientific method (Suparno, 2007). The syntax of the guided inquiry learning model consists of presenting problems, formulating hypotheses, designing and conducting experiments, collecting and analyzing data, making conclusions, and communicating the results of the study (Sulistijo et al., 2017). In the experimental class, the inquiry stage was carried out at each syntax by providing guidance to 
students in order to find the intent of the learning indicators to be achieved, while in the control class the inquiry stage was only given when students designed and conducted experiments during the process. As for the guidance given, students designed and conducted experiments in the experimental class. Thus, this activity then leads to the data collecting. Data were presented tools and experimental materials vibration and wave students are guided to determine the variables, objectives, and experimental procedures as well as measuring and taking data. While in the control class guidance was given when students designed and conducted experiments, namely by providing demonstrations of vibrations and waves practicum experiments. The difference in treatment provided the experiment aims to measure the parameters. Then the achievement of science process skills both in the control class and the experimental class were gained. The stages of data analysis were ended then inferred and compared between the two classes.

This type of research is an experimental study. Specifically, the design of this research is quasiexperiment with non-equivalent control group design to determine the results. The research subjects in this study were state junior high school or Sekolah Menengah Atas (SMP) students in Yogyakarta in the academic year 2018/2019. Data collection techniques consisted of non-test and test techniques. Non-test techniques were used to observe the achievement or improvement of students' science process skills directly during the process of experimental activities (Facione, 1990). The instrument used was designated observation sheet. Observation sheet was required to observe the implementation of learning during the experiment (Corebima, 2008; Hake, 1999; Khasanah et al., 2017).

The test technique used in this study were test instruments consisted of pretest and post-test. Before the learning and research instruments were used, both instruments were validated logically and empirically. Logical validation was carried out by several experts related to the field then the validation results were analyzed using VAiken. Logical validation was analyzed using product moment correlation (Bashir \& Bala, 2018; Sadhu \& Laksono, 2018). Data obtained from the results of the study were then subjected to the analysis prerequisite test, namely the normality and homogeneity tests (Aiken, 1985; Mardapi, 2008). Furthermore, the research data were tested by testing the hypothesis and measuring the increase in $\mathrm{N}$-Gain value of students' science process skills.

\section{RESULT AND DISCUSSION}

Based on the validation to the test results for the learning instrument, it was obtained that the VAiken value was 1.00 . The value was included in both categories. It means that the learning instruments including worksheets can be used for research. As for the results of the analysis to the observation sheet of science process skills using V-Aiken, it was obtained that the value was 0.95 . The value was included in both categories. It means that the science process skills observation sheet instrument can also be used for research. After the validation results were determined, then the prerequisite test was conducted.

The analysis of prerequisite test results was used to determine the statistics that will be used for research data analysis. If the data is normally distributed, then the statistics analysis was using parametric statistics. However, if the data are not normally distributed, then the statistics analysis was using non-parametric statistics. The analysis prerequisite test referred to is the normality and homogeneity test conducted on the pretest and post-test data of science process skills indicators which were then processed and analyzed using SPSS software. Based on the prerequisite test, the results showed that the data were not normally distributed, so the statistics used in this study were non-parametric statistics, i.e. conducted further tests using the Mann Whitney Test (UTest) to hypotheses testing. 
The initial ability of students was obtained from the pretest scores obtained before the two groups before receiving treatment. The pretest values were then analyzed statistically using the MannWhitney Test with the help of SPSS. The results of the analysis are presented in Table 2.

Table 2. The Results of Mann Whitney Test to Pretest Data of Science Process Skills

\begin{tabular}{|c|c|c|c|c|c|c|}
\hline Class & $\mathbf{N}$ & $\mathbf{Z}_{\text {obtained }}$ & df & $\begin{array}{c}\text { Asymp. Sig } \\
\text { (2-tailed) }\end{array}$ & $\alpha$ & $\begin{array}{c}\text { Interpret } \\
\text { ation }\end{array}$ \\
\hline Exp. & 30 & \multirow{2}{*}{-0.352} & \multirow{2}{*}{60} & \multirow{2}{*}{0.725} & \multirow{2}{*}{0.05} & There is \\
\hline Ctrl & 30 & & & & & $\begin{array}{c}\text { no } \\
\text { difference }\end{array}$ \\
\hline
\end{tabular}

Whether there is a difference or not in the average score of students' pretest data of the experimental class and the control class can be seen based on the Asymp. Sig (2-tailed) value compared with a significance level or alpha $(\alpha)$ of $5 \%$ or 0.05 . Based on Table 3, it can be seen that the Asymp. Sig (2-tailed) value is 0.725 , which means it is greater than the significance level $\alpha$. This shows that the initial abilities of students were the same or there was no difference before both classes were being given the treatment. Furthermore, differences in learning outcomes of the science process skills of the experimental class and control class students were seen from the posttest data. Post-test data were tested with Mann Whitney test statistics with the help of SPSS. The results of the analysis are presented in Table 3.

Table 3. The Results of Mann Whitney Test to Post-test Data of Science Process Skills

\begin{tabular}{ccccccc}
\hline Class & $\mathbf{N}$ & $\mathbf{Z}_{\text {obtained }}$ & $\mathbf{d f}$ & $\begin{array}{c}\text { Asymp. Sig } \\
\text { (2-tailed) }\end{array}$ & $\boldsymbol{\alpha}$ & $\begin{array}{c}\text { Interpret } \\
\text { ation }\end{array}$ \\
\cline { 1 - 5 } Exp. & 30 & -2.918 & 66 & 0.004 & 0.05 & $\begin{array}{c}\text { There is } \\
\text { difference }\end{array}$ \\
\cline { 1 - 2 } Ctrl & 30 & & & & &
\end{tabular}

Based on Table 3, it can be seen that the Asymp. Sig (2-tailed) value is 0.004 . It means that the value obtained was smaller than the significance level $\alpha$, so it could be said that Ha was accepted. This finding showed that there is a significant difference between students' science process skills pattern between the experimental class and the control class after treatment was being given to the experimental class.

The difference in science process skills possessed by students in detail is presented in Table 5 . Based on the finding, there is an increase in science process skills in the aspects of conducting experiments which have an N-Gain value of 0.372 and was categorized in the medium category. This shows there were differences in science process skills possessed by students before and after treatment. In the experimental class, when presented with tools and experimental material, students were guided to be able to design and conduct experiments. Meanwhile in the control class, the effort was to stimulate students in designing and conducting experiments and the teacher gave a demonstration first.

The average difference in students' science process skills cannot be separated from the stages of learning using guided inquiry learning model that had facilitated students in practicing their science process skills during the lesson. In the questioning activity of guided inquiry syntax which was formulating hypotheses, we found that the guided inquiry learning model was able to facilitate students' scientific process skills, namely hypothesizing. In addition to the activities of exploring the syntax of guided inquiry learning to the steps of designing and conducting experiments, we found that the elevating students' science process skills could be facilitated by the guided inquiry learning model in the class.

In the experimental class in each syntax, the teacher guides students to achieve indicators of science process skills. In the stage of presenting problems and formulating hypotheses, students are guided to hone their scientific process skills, namely observing and hypothesizing. In the stage of designing and conducting an experiment the teacher guides students to be able to design the experiments and analyze the results of the experiments that have been conducted then 
students make conclusions to be communicated in front of the class as well as to clarify and reflect on the learning outcomes. Figure 1 showed the difference pattern of learning in the classroom. There was difference of results and students' activity in doing the experiment. Both lead to the different learning outcomes.

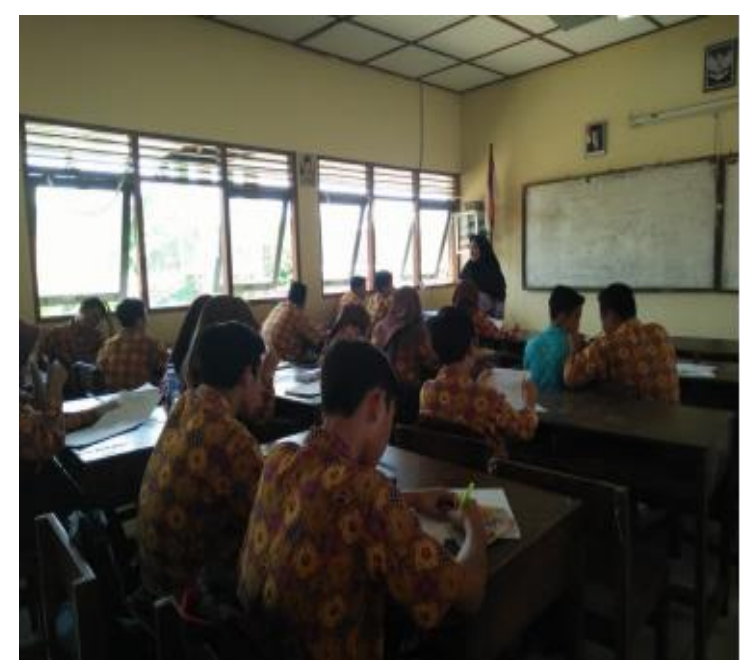

(a)

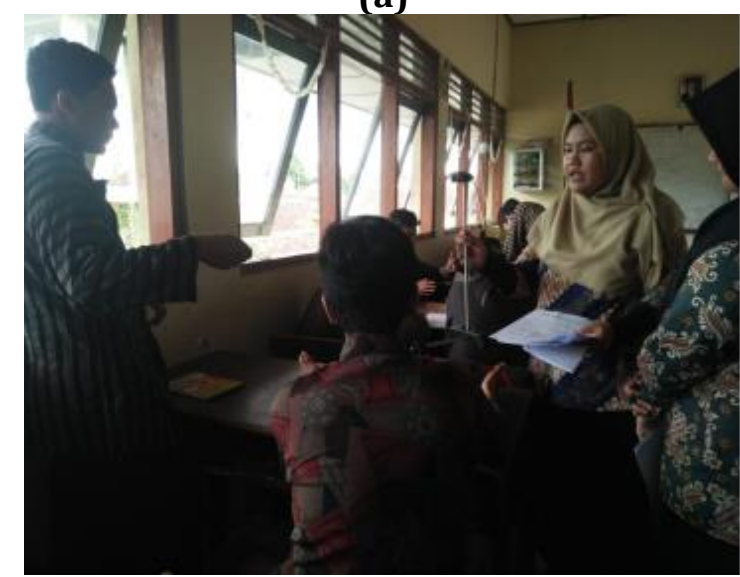

(b)

Figure 1. (a) Teachers gave the learning material then brought the tools and materials to support the demonstration time of vibration, wave, and sound; (b) Teachers gave the guidance to students to arrange, design, and conduct the experiment of vibration, wave, and sound using the tools and material to support it.
Figure 1(a) shows the experiment in control class. Students were obtained to look for the experiment lead by the teacher. Meanwhile, Figure 1(b) shows the experiment conducted in experimental class. Students were doing the experiment they have designed before and conducted the experiment through materials and tools. The implementation in both classes were quite good and the research design was done comprehensively. The analysis of research implementation influenced the research results.

Learning process by using guided inquiry learning model in the experimental class was able to stimulate students to be able to design experiments and formulate hypotheses. Then, students could find the essential meaning about the material being studied (gain conceptual understanding). Whereas the control class only emphasized the mastery of the material and the ability of students to work on problems and use practical tools. As a result, students' science process skills were not honed. Improved cognitive learning outcomes could be seen from the results of the $\mathrm{N}$-Gain test in pretest and posttest score between the experimental class and the control class. The results of the analysis are presented in Table 4.

Table 4. The Results of N-Gain Test of Science Process Skills

\begin{tabular}{cccccc}
\hline \multicolumn{7}{c}{ Mean } \\
\hline Class & $\mathbf{N}$ & $\begin{array}{c}\text { Pre- } \\
\text { test }\end{array}$ & $\begin{array}{c}\text { Post- } \\
\text { test }\end{array}$ & $<$ g $>$ & Classification \\
\hline Exp. & 33 & & & & \\
\hline Ctrl & 33 & 17.878 & 22.424 & 0.431 & Medium \\
& 32 & 16.696 & 19.151 & 0.217 & Low \\
\hline
\end{tabular}

Table 4 shows that the $\mathrm{N}$-Gain classification of the experimental class and the control class differ. The experimental class N-Gain value was 0.431 and included in the medium classification, while the control class N-Gain value was 0.217 and included in the low classification. Based on the values in Table 5, it could be said that learning with the guided inquiry model could improve students' science process skills. 
Improved science process skills were obtained from the average N-Gain score. Based on Table 5, it appears that the $\mathrm{N}$-Gain classification of the experimental class and the control class were different. This shows that learning with the guided inquiry model could improve students' science process skills. For more details, the following Table 5 is presented, which contains NGain descriptions for each indicator of science process skills in the experimental class.

Table 5. Description on N-Gain Value to Each Indicator of Science Process Skills

\section{Indicator of Science Process Skills}

\section{$\mathrm{N}$-Gain of \\ Experimental Category \\ Class}

\begin{tabular}{lcc}
\hline $\begin{array}{l}\text { Observe } \\
\text { Understanding the phenomenon of vibration in the pendulum swing and } \\
\text { observing the phenomenon of waves on the rope and sound. }\end{array}$ & 0.86 & Medium \\
\hline $\begin{array}{l}\text { Formulate the Hypothesis } \\
\text { Compiling and predicting hypotheses from phenomena of vibration, waves and } \\
\text { sound. }\end{array}$ & 0.408 & Medium \\
\hline $\begin{array}{l}\text { Design the Experiment } \\
\text { Designing and creating simple experiments for the phenomenon of vibration, } \\
\text { waves and sound. }\end{array}$ & 0.100 & Low \\
\hline $\begin{array}{l}\text { Conduct the Experiment } \\
\text { Conducting experiments to measure quantities of vibrations, waves and sounds. }\end{array}$ & 0.372 & Medium \\
\hline $\begin{array}{l}\text { Analyze Data } \\
\text { Analyzing waves based on the direction of propagation (transversal waves and } \\
\text { longitudinal waves). }\end{array}$ & 0.351 & Medium \\
\hline $\begin{array}{l}\text { Conclude } \\
\text { Applying the concepts of vibrations, waves and sounds to technology. }\end{array}$ & 0.303 & Medium \\
\hline $\begin{array}{l}\text { Communicate } \\
\text { Presenting the results of the experiment and identification in the form of a } \\
\text { written report and discuss it with friends. }\end{array}$ & 0.183 & Low \\
\hline
\end{tabular}

The following will discuss the results of the $\mathrm{N}$ Gain on each indicator of science process skills that have been presented in Table 5 due to the description of n-gain value of each indicator of science process skills.

\section{Observation}

Observing is one of the fundamental scientific skills (Nasir et al., 2019). Observing is not the same as seeing. Observing is the ability to gather facts, find similarities and object the differences by using some or all of the senses in the human body (Mangurai, 2017). Observing is the basis for all other process skills, the results of observing can be continued to carry out the process of measuring, classifying, making inferences or skills to communicate the results of observations based on the analysis and calculation.

In the aspect of observing, observation sheets and worksheets were made to meet the indicators of science process skills i.e. students are able to use the appropriate senses to determine and gather facts relevant to vibrations, waves, and sounds. Based on Table 6, it is known that the N-Gain value for the observing indicator in this study is 0.386. It was included in the medium criteria.

\section{Formulating Hypothesis}

Formulating hypothesis is the ability to state the relationship between two variables and propose an estimate of the cause of something happening (causality) (Anam, 2015; Nworgu \& Otum, 2013; 
Prabowo, 2015). The truth of the hypothesis will be tested through experimentation (Rustaman et al., 2005; Trianto, 2014). Observation sheets and worksheets are made on aspects of formulating hypotheses that meet the indicators of science process skills, namely formulating hypotheses about observational objects based on vibrations, waves, and sounds. Based on Table 6, it is noted that the $\mathrm{N}$-Gain value for science process skill indicators is 0.408 . It was included in the medium criteria.

\section{Designing Experiment}

Designing experiment is an activity to plan the attempts in carrying out hypotheses testing, examining the truth or paying attention to the principles or facts that are known. Skills for designing experiment include the ability to determine the variables to be observed and measured, determine the tools and materials to be used in an experiment, and determine the steps of the experiment to be taken.

Observation sheet and worksheet in the aspects of designing an experiment meet the indicators of science process skills, namely determining the variables and tools / materials of vibration, wave, and sound experiments. Based on Table 6 , it is known that the $\mathrm{N}$-Gain value for the indicator designing the experiment is 0.100 which is in the low criteria. Although the criteria for designing aspects of the experiment belong to the low category, the students' answers about the experiment variables have increased. In this activity, students have been given tools and materials for the experiment, then students are asked and guided to determine the tools and materials used related to influence in the experiment.

\section{Conducting Experiment}

In the aspect of conducting experiments, the observatory and worksheets are made to meet the indicators, namely conducting experiments on vibrations, waves, and sounds in accordance with predetermined procedures. Based on Table 6 , it is known that the N-Gain value for the indicator of science process skills is 0.372 , which is in the medium criteria. At this stage, after students determined the tools and materials in the experiment, students then determined the procedure of the experiment by filling in the student worksheets. After that, students were then conducting an experiment to retrieve data.

\section{Analyzing Data}

Analyzing data is the ability to connect the results of experiments and find patterns from a number of data collected then draw conclusions from the results of experiments. The data presented can be further interpreted into a logical explanation through descriptive analysis. In analyzing aspects, observation sheet and worksheet are made to meet the indicators, namely processing and calculating the results of vibration, wave, and sound experimental results. Based on Table 6, it is known that the value of $\mathrm{N}$-Gain for science process skill indicators is 0.351 , which is in the medium criteria.

\section{Concluding the Results}

In concluding the results aspect, the problem is made to meet the indicator that is determining conclusions in accordance with the observational data and connecting with vibrations, waves, and sounds scientific concepts. Based on Table 6, it is known that the $\mathrm{N}$-Gain value for the indicator of science process skills is 0.303 , which is in the medium criteria. At this stage, students concluded the results of the experiment while being able to find concepts in the material vibrations, waves, and sounds.

\section{Communicating}

Communicating can lead to interpreting data, facts, concepts, and principles of science in the form of audio, visual, or audio visual during the learning process. Communication skills are the ability to explain the results of experiments through discussion activities, describe empirical data with graphs or tables or diagrams, compile and submit reports on the results of experiments based on the experience. 
Observation sheet and students' worksheet in the communicating aspect are made to meet the indicators of science process skills, namely presenting observational data from one form to another on vibration, wave, and sound material. Based on Table 6, it is known that the N-Gain value for the indicator designing the experiment is 0.183 , which is in the low criteria. Although the criteria for designing aspects of the experiment belong to the low category, the students' answers about the experiment variables have increased properly and it showed the significant impact. At this stage, students wrote the conclusions then conveyed to the class related to the results of the experiments that have been conducted.

The guided inquiry learning model in this study had revealed that the escalation in students' science process skills could be gained if the stages of scientific method applied. The findings in this study was also supported by former research done by (Ma'ruf, M. \& Novianti, 2016). The research found that guided inquiry model can be used to improve the physics learning outcomes in students on chapter static fluid. Other research also found that guided inquiry learning model was able to enhance student' conceptual understanding and students' cognitive abilities (Zamista \& Kaniawati, 2015).

\section{CONCLUSION}

Referring to the formulation of the problem based on the results of research and analysis conducted, consequently the following conclusions are obtained and resumed in two findings:

1) Learning physics using guided inquiry learning model has an effect on students' science process skills in the material of vibrations, waves and sounds with a significance level (sig. 2-tailed) of 0.004 . This value was less than significance value $\alpha=$ 0.05 . It means that Ha is accepted and Ho is rejected.
2) Learning physics using guided inquiry learning model can improve and elevate students' science process skills in vibrations, waves, and sounds material. It is known through the average $\mathrm{N}$-Gain value of 0.431 , which is categorized into the medium criteria based on statistics calculation.

\section{REFERENCES}

Aiken, L. R. (1985). Three coefficients for analyzing the reliability and validity of ratings. Educational and Psychological Measurement, 45(1), 131-142.

Anam, K. (2015). Pembelajaran Berbasis Inkuiri metode dan aplikasi. Yogyakarta: Pustaka Pelajar.

Bashir, H., \& Bala, R. (2018). Development and validation of academic dishonesty scale (ADS): Presenting a multidimensional scale. International Journal of Instruction, 11(2), 57-74.

Corebima, A. D. (2008). Review on: Learning strategies having bigger potency to empower thinking skill and concept gaining of lower academic students. Redesigning Pedagogy International Conference.

Dahar, R. W. (1988). Teori-teori belajar. Departmen Pendidikan dan Kebudayaan, Direktorat Jenderal Pendidikan Tinggi ....

Deta, U. A., \& Widha, S. (2013). Pengaruh Metode Inkuiri Terbimbing dan Proyek, Kreativitas, serta Keterampilan Proses Sains terhadap Prestasi Belajar Siswa. Jurnal Pendidikan Fisika Indonesia, 9(1).

Facione, P. A. (1990). The California Critical Thinking Skills Test--College Level. Technical Report\# 1. Experimental Validation and Content Validity.

Funk, H. J. (1985). Learning science process skills. ERIC.

Hake, R. R. (1999). Analyzing Change/Gain Scores. American Eduational Research Asociation's DivisionsD, Measurement and Reseacrh Methoology, 1-4.

Istiyono, E., Mardapi, D., \& Suparno. (2014). Pengembangan Tes Kemampuan Berpikir 
Tingkat Tinggi (PysTHOTS) Peserta Didik SMA. Jurnal Penelitian Dan Evaluasi Pendidikan, 18(1), 1-12.

Kemdikbud, R. I. (2017). Panduan Pengembangan Pembelajaran Aktif. Jakarta: Direktorat Pembinaan SMA.

Khasanah, A. N., Widoretno, S., \& Sajidan, S. (2017). Effectiveness of Critical Thinking Indicator-Based Module in Empowering Student's Learning Outcome in Respiratory System Study Material. Jurnal Pendidikan IPA Indonesia, 6(1), 120425.

Ma'ruf, M.; Novianti, N. (2016). Implementation of Guided Inquiry Learning. 5(1), 159-166.

Mangurai, S. M. (2017). Peningkatan Keterampilan Proses Sains Menggunakan Model Inkuiri Terbimbing dan Performance Assesment pada Siswa XI IPA 1 SMA Kristen 1 Salatiga Tahun Ajaran 2016/2017. Proceeding Biology Education Conference: Biology, Science, Enviromental, and Learning, 14(1), 325-326.

Mardapi, D. (2008). Teknik penyusunan instrumen tes dan nontes. Yogyakarta: Mitra Cendikia Press.

Nasir, M., Fakhrunnisa, R., \& Nastiti, L. R. (2019). The Implementation of Project-based Learning and Guided Inquiry to Improve Science Process Skills and Student Cognitive Learning Outcomes. International Journal of Environmental and Science Education.

Nworgu, L. N., \& Otum, V. V. (2013). Effect of guided inquiry with analogy instructional strategy on students acquisition of science process skills. Journal Education and Practice 4,(27) 35, 40.

Prabowo, S. A. (2015). The effectiveness of scientific based learning towards science process skill mastery of PGSD students. Jurnal Pendidikan IPA Indonesia, 4(1), 15-19.

Rustaman, N., Dirdjosoemarto, S., Yudianto, S. A., Achmad, Y., Subekti, R., Rochintaniawati, D., \& Nurjhani, M. (2005). Strategi belajar mengajar biologi. Malang: UM press.

Sadhu, S., \& Laksono, E. W. (2018). Development and Validation of an Integrated Assessment for Measuring Critical Thinking and
Chemical Literacy in Chemical Equilibrium. International Journal of Instruction, 11(3), 557-572.

Semiawan, C. (n.d.). AS \& Munandar, SCU (1990) Memupuk Bakat dan Kreativitas Siswa Sekolah Menengah. Petunjuk Bagi Guru Dan Orang Tua. Jakarta: PT Gramedia.

Sulistijo, S. H., Sukarmin, S., \& Sunarno, W. (2017). Physics Learning Using Inquiry-Student Team Achievement Division (ISTAD) and Guided Inquiry Models Viewed by Students Achievement Motivation. Jurnal Pendidikan IPA Indonesia, 6(1).

Suparno, P. (2007). Metodologi pembelajaran fisika. Yogyakarta: Universitas Sanata Dharma.

Trianto, I. B. (2014). Mendesain model pembelajaran inovatif, progresif, dan kontekstual. Jakarta: Prenadamedia Group.

Wartono, W., Batlolona, J. R., \& Mahfi, R. M. (2019). PENINGKATAN KEMAMPUAN PEMECAHAN MASALAH FISIKA DENGAN MODEL PEMBELAJARAN INQUIRY-DISCOVERY. EDUSAINS, 11(2), 242-248.

Winarti, W. (2020). Peran Pendidik Fisika Dalam Mempersiapkan Society 5.0. Prosiding SNPF (Seminar Nasional Pendidikan Fisika).

Zamista, A. A., \& Kaniawati, I. (2015). Pengaruh model pembelajaran process oriented guided inquiry learning terhadap keterampilan proses sains dan kemampuan kognitif siswa pada mata pelajaran fisika. Edusains, 7(2), 191-201. 